\title{
At What Scales and Why Does Forest Structure Vary in Naturally Dynamic Boreal Forests? An Analysis of Forest Landscapes on Two Continents
}

\author{
Kulha, Niko Aleksi
}

2019-06

Kulha, N A , Pasanen , L , Holmström , L , Grandpre , L D , Kuuluvainen , T T \& Aakala , T 2019 , ' At What Scales and Why Does Forest Structure Vary in Naturally Dynamic Boreal Forests? An Analysis of Forest Landscapes on Two Continents ' , Ecosystems , vol. 22 , no. 4 , pp. 709-724 . https://doi.org/10.1007/s10021-018-0297-2

http://hdl.handle.net/10138/303115

https://doi.org/10.1007/s10021-018-0297-2

acceptedVersion

Downloaded from Helda, University of Helsinki institutional repository.

This is an electronic reprint of the original article.

This reprint may differ from the original in pagination and typographic detail.

Please cite the original version. 
Scales of variation in boreal forests

1 At what scales and why does forest structure vary in naturally dynamic boreal

2 forests? An analysis of forest landscapes on two continents

4 Niko Kulha*, Leena Pasanen, Lasse Holmström, Louis De Grandpré, Timo Kuuluvainen, Tuomas

5 Aakala

6

$7 \quad$ N. Kulha, T. Kuuluvainen, T. Aakala

8 Department of Forest Sciences, University of Helsinki. P.O. Box 27, FI-00014 Helsinki, Finland

9

10 L. Pasanen, L. Holmström

11 Research Unit of Mathematical Sciences, University of Oulu. P.O. Box 8000, FI-90014 Oulu,

12 Finland

13

14 L. De Grandpré

15 Canadian Forest Service, Laurentian Forestry Centre. P.O. Box 3800, Sainte-Foy, Quebec GIV

16 4C7, Canada

17

$18 *$ Corresponding author.

19 OrcID: 0000-0002-1610-9938

20 Tel. +358405011588

21 E-mail address: niko.kulha@helsinki.fi

TA designed the study. NK interpreted the aerial photographs, and TA, TK, and LD collected the field data. LP and LH developed the analysis methods, and LP and NK conducted the analyses. NK, LP, and TA wrote the first draft of the paper, and all authors contributed to writing the final version. 
Scales of variation in boreal forests

Identifying the scales of variation in forest structures and the underlying processes are fundamental for understanding forest dynamics. Here, we studied these scale-dependencies in forest structure in naturally dynamic boreal forests on two continents. We identified the spatial scales at which forest structures varied, and analyzed how the scales of variation and the underlying drivers differed among the regions and at particular scales.

We studied three $2 \mathrm{~km} \times 2 \mathrm{~km}$ landscapes in northeastern Finland and two in eastern Canada. We estimated canopy cover in contiguous 0.1 -ha cells from aerial photographs and used scalederivative analysis to identify characteristic scales of variation in the canopy cover data. We analyzed the patterns of variation at these scales using Bayesian scale space analysis.

We identified structural variation at three spatial scales in each landscape. Among landscapes, the largest scale of variation showed greatest variability (20.1 - 321.4 ha), related to topography, soil variability, and long-term disturbance history. Superimposed on this large-scale variation, forest structure varied at similar scales $(1.3-2.8$ ha) in all landscapes. This variation correlated with recent disturbances, soil variability, and topographic position. We also detected intense variation at the smallest scale analyzed ( 0.1 ha, grain of our data), partly driven by recent disturbances.

The distinct scales of variation indicated hierarchical structure in the landscapes studied. Except for the large-scale variation, these scales were remarkably similar among the landscapes. This suggests that boreal forests may display characteristic scales of variation that occur somewhat independent of the tree species characteristics or the disturbance regime. 
Scales of variation in boreal forests

$47 \quad$ Keywords

48 Forest dynamics, Canopy cover, Aerial photography, Bayesian inference, Eastern Canada, Northern

49 Fennoscandia

50

\section{Manuscript highlights}

52 - We identified distinct scales of hierarchical variation in boreal forest structure

53 - The mid-scale variation occurred at remarkably similar scales among the landscapes

54 - Drivers of the structural variation depended on the observation scale 
Scales of variation in boreal forests

\section{Introduction}

The spatial variability of forest structure (e.g., tree sizes, distribution of stems and foliage, dead wood) is the result of multiple factors such as disturbances, succession, topography, and soil properties (Lavoie and others 2007; Gauthier and others 2010; Walker and Johnstone 2014). Knowledge of this structural variation is essential for understanding the processes that drive forest dynamics, habitat variability, and biodiversity (Niemelä and others 1996; Kuuluvainen and others 2017), along with nutrient and carbon dynamics (Wickland and Neff 2008; Bradshaw and others 2009) in forested landscapes.

Forest structure varies hierarchically at multiple spatial scales (Kotliar and Wiens 1990;

Kuuluvainen and others 1998). However, the scales at which the variation occurs are often only described qualitatively (Angelstam and Kuuluvainen 2004; Bouchard and others 2008; Kuuluvainen and others 2014). The multiscale variation reflects the influence of drivers that shape forest structure at different scales, and their cumulative effects (Elkie and Rempel 2001; Wong and Daniels 2016). Some drivers create variation across multiple spatial scales. For example in the

71 boreal forest, topography and soil properties may create variation at the landscape scale by changing the predisposition of stands to high winds (Ruel and others 1998) and by influencing the tree species composition (Sutinen and others 2002), and at the small, within-stand scales, by influencing the occurrence of suitable regeneration sites (Kuuluvainen and Kalmari 2003; Grenfell and others 2011). Similarly, disturbances such as forest fire may induce variation at the landscape scales (De Grandpré and others 2000; Gauthier and others 2010), while insect outbreaks and wind disturbances typically create variation at stand scales (Kuuluvainen and others 1998; Pham and others 2004). The influence of some other drivers, such as tree-tree competition (Aakala and others 
Scales of variation in boreal forests

2016), or the senescence-related deaths of individual trees (Aakala and others 2009) is limited to within-stand scales.

Studies on forest structures and dynamics often focus on a priori-selected scale, or on the effect of a specific driver. However, as structural variation occurs at multiple scales and results from multiple drivers, a single scale or focus on a specific driver is often insufficient for comprehensive landscape analysis (Habeeb and others 2005; Scholes 2017; Estes and others 2018). Furthermore, the patterns of structural variation and their linkages to the drivers of variation have a fundamental connection with the spatial scale of observation (Wu and Loucks 1995), highlighting that studies on forest structural variability would benefit from methods that do not rely on scales selected a priori (Hay and others 2002). Instead, the complex nature of forest ecosystems requires an analysis of patterns in forest structures and the underlying processes in which the scales of observation are reduced to those containing the most salient features (i.e. the characteristic scales of variation; Wu 1999). The identification of such scales is the first step towards understanding the multiscale linkages of ecological patterns and processes (Scholes 2017).

Here, we studied the scale-dependent variation in boreal forest structure and the factors influencing this variation. We hypothesized that in forest landscapes (1) structural variation occurs at specific, discernible spatial scales, but (2) these discernible scales of variation differ between regions and landscapes, and (3) we can identify different (scale-dependent) drivers of structural variation behind these patterns.

We tested these hypotheses in five naturally dynamic boreal forest landscapes in two regions, northern Finland and northeastern Quebec, Canada. Using visual interpretation of canopy cover variation on recent aerial photographs calibrated against field measurements, we applied scale- 
Scales of variation in boreal forests

104 derivative analysis (Pasanen and others 2013) and Bayesian scale space multiresolution analysis

105 (Holmström and others 2011). These methods aim to recognize characteristic scales of forest

106 structural variation, assess the spatial occurrence of structural variation, and identify structurally

107 distinct areas in the study landscapes.

108

109 Material and Methods

110 Study area

111

112 We examined forests in two regions: northeastern Finland $\left(67^{\circ} 44^{\prime} \mathrm{N}, 2^{\circ} 33^{\prime} \mathrm{E}\right)$ and the North Shore

113 region in Quebec, Canada (49³8' N, 6755' W; Fig. S1). In Finland, we examined two landscapes

$114(2 \mathrm{~km} \times 2 \mathrm{~km})$ in Värriö Strict Nature Reserve (Hirvaskangas and Pommituskukkulat), and a third

115 landscape in Maltio Strict Nature Reserve (Hongikkovaara). In Quebec, we studied two landscapes, 116 Lac Dionne and Pistuacanis.

117

118 The studied landscapes are mosaics of forests on mineral soil, waterbodies, and forested and open

119 peatlands. Soils in northeastern Finland consist mostly of undifferentiated glacial tills, with gentle

120 slopes, and low mountain fells with treeless upper slopes. The elevation ranges between 200 and

121500 meters above sea level (asl). In the North Shore region of Quebec, slopes vary from low to

122 moderate. Undifferentiated glacial tills are common on the gentle slopes and depressions, as are

123 glaciofluvial sand deposits in floors of larger valleys and rocky outcrops on moderate slopes and

124 summits (Robitaille and Saucier 1988). Here, the elevation of the studied region ranges from 300 to

125500 meters asl. Northern Finland has a subcontinental climate, with an annual mean temperature of

$126+0.9^{\circ} \mathrm{C}$. The climate in the North Shore region is humid, with an annual mean temperature of

$127+0.3{ }^{\circ} \mathrm{C}$ (see Supplementary material 1 for details). 
Scales of variation in boreal forests

129 Low tree species diversity is characteristic of both regions. The main tree species in Finnish

130 landscapes are Pinus sylvestris (L.), Picea abies (L.) Karst, and Betula pubescens (Ehrh.). Picea

131 mariana (Mill.) and Abies balsamea (L.) Mill. dominate in Quebecois landscapes. The tree species

132 composition of both regions reflects site productivity and long-term disturbance history

133 (Supplementary material 1).

Visual interpretation of canopy cover

To quantify forest structural variation at various spatial scales, we first visually interpreted canopy cover from recent aerial photographs in each of the five study landscapes. We used stereopairs of false-color aerial photographs with a pixel size of $0.5 \mathrm{~m}$. Photographs for northern Finland were obtained from the National Land Survey of Finland, and were taken during summers 2011 (Hirvaskangas and Pommituskukkulat) and 2010 (Hongikkovaara). Photos for Quebec were obtained from the Ministère des Forêts, de la Faune et des Parcs du Québec, and were taken in 2011. We performed the stereointerpretation with EspaCity software (version 11.0.15306.1; Espa Systems Ltd., Espoo, Finland), using a passive 3D monitor.

During the interpretation, we visually estimated canopy cover in 0.1-ha cells. For this, we placed a square grid of $64 \times 64$ cells over each landscape. To reduce bias due to improving interpretation skill, we divided the grids into sixteen parts (256 cells each), and the first author interpreted these sub-grids in randomized order. For each cell, we recorded total canopy cover and the proportion of various tree species. We identified conifers to species level, but did not separate deciduous trees.

151 We estimated canopy cover as the proportion of forest floor covered by the vertical projection of a 152 tree crown. Further, we counted the number of standing and fallen dead trees, which we later used 153 as a measure of recent disturbances (see below). If a cell was not completely within a forest (e.g., 
Scales of variation in boreal forests

waterbody, open peatland), we excluded it from further analyses. In Pommituskukkulat, we also excluded cells overlapping or bordering a reindeer fence traversing the area.

\section{Calibration of and error in the visual interpretation}

To reduce bias in the visual interpretation and to quantify the interpretation error, we field-sampled randomly selected grid cells, and reconstructed canopy cover for these cells at the year corresponding to the aerial photographs. In Finland, we sampled 16 cells per landscape (as described in Aakala and others 2016). In Quebec, logistical constraints limited the sample size to nine cells per landscape. In each sampled cell, we mapped all living and dead trees with a minimum diameter of $10 \mathrm{~cm}$ at $1.3 \mathrm{~m}$ height whose crown reached within the cell. We extracted samples for tree-ring width measurements from each tree (see Supplementary material 2 for details). For live trees, we mapped crown projections by measuring $4-8$ points along the crown dripline. We converted the crown measurements into irregular polygons and used the tree-ring width measurements to reconstruct the crown sizes corresponding to the year the aerial photograph for that landscape was taken. We used species-specific regression models between tree diameter and crown projection area to convert change in tree size to change in crown size (Figs. S2 - S3). We used tree-ring widths to cross-date the year of death for the sampled dead trees, and assumed circular crowns for trees that died between field sampling and the year the aerial photograph was taken. From the reconstructions, we calculated the canopy cover of the sampled cells as the nonoverlapping sum of individual crown projections.

We calibrated the visual interpretation and quantified the interpretation error using regression models between the interpreted and reconstructed canopy covers for Finnish and Quebecois landscapes individually (Figure 1; see Supplementary material 3 for details). We tested the 
Scales of variation in boreal forests

179 influence of additional variables (tree species proportions, distance from cells to aerial photograph

180 nadirs) for the calibration model in the Finnish landscapes. According to Akaike information

181 criterion for small sample sizes (AICc), the model fit improved when we included the proportion of

$182 P$. abies in the cell as a predictor (Table S1). Hence, we included it in the final calibration model for

183 the Finnish landscapes (Fig. S4). We then compiled the calibrated canopy cover values into raster

184 maps, and used the interpretation error (i.e. the residuals of the calibration model) in Bayesian

185 inference (see below).

186

187 Similar to canopy cover, we calibrated the visual interpretation of the number of snags and logs

188 (minimum diameter $10 \mathrm{~cm}$ at $1.3 \mathrm{~m}$ height) in each cell with the equivalent dead wood basal area

189 measured in the field (Figs. S5 - S6). Zero snags and logs were interpreted in many grid cells.

190 Hence, the dead wood posterior predictive samples could have had negative draws (negative dead

191 wood basal area). We tested the influence of the negative samples to the results by replacing all the

192 negative draws in the samples with zero. Truncation of the negative values did not affect the

193 interpretation of the results (Supplementary material 3).

Identification of the scales and spatial patterns of canopy cover variation

198 Our aims were to identify spatial scales of variation for each landscape, and to assess the spatial

199 patterns of this variation at the identified scales. For this, we used Bayesian scale space

200 multiresolution analysis (Holmström and others 2011). The use of this approach on a canopy cover

201 raster map relies on the idea that the raster consists of a sum of components of various spatial

202 scales. Hence, smoothing the raster can reveal features that correspond to a signal at various scales.

203 A low smoothing level maintains all but the smallest-scale variation in the signal, and a high level 
Scales of variation in boreal forests

of smoothing evens out the small-scale details and reveals only locally average behavior in the signal. To extract the relevant scales of variation and study the features at each particular scale separately (as suggested by e.g., O’Neill and others 1986), the scale space multiresolution analysis considers the differences of smooths, where a smooth with a higher smoothing level is subtracted from a smooth with a lower smoothing level. We henceforth call the product of this subtraction (signal at a particular scale) the 'scale-dependent component'.

The analysis consists of five steps (Fig. 1): 1) calibration of the visual interpretation, 2) scale identification, 3) multiresolution decomposition, 4) credibility assessment, 5) feature size estimation that are next described in more detail.

In step 1, based on the calibration models described above, we built a Bayesian model for the calibrated canopy covers using the interpreted and field-measured canopy cover (see Supplementary material 3 for details).

In step 2, the scales of variation are identified. The identification of the spatial scales at which the most salient features in the raster maps occur requires that the smoothing levels are determined carefully. For this, we used an objective approach based on a concept of 'scale-derivative', which refers to the derivative of a signal smooth with respect to the logarithm of the smoothing level (Pasanen and others 2013). The relevant scales are detected based on the locations of local minima of a scale-derivative vector norm. In brief (see Pasanen and others 2013 for full details), consider a signal that consists of a sum of two components of different scales. The location of a local minimum then represents a scale at which the smaller scale component is smoothed out, revealing the larger-scale component not yet affected by smoothing. Hence, the signal including the smallscale variation can be recovered as the difference between the original signal and the smooth 
Scales of variation in boreal forests

corresponding to the local minimum. In general, a smoothing level sequence is defined using such local minima of the scale-derivative norm, and the variations at different scales (i.e. scale-dependent components) are resolved as the differences between the smooths of two consecutive smoothing levels. Henceforth, we call these identified local minima as scale breaks (sensu Wu 1999).

In the context of forest structure, a scale break represents a transition between hierarchical levels of variation. Within a variation level, the first break represents the grain and the second the extent of the particular level. In our analysis, the scale-derivative did not always detect the scale breaks automatically. In such cases, we visually searched the norms for weaker signs of scale breaks such as saddle points or changes in slope. We verified the existence of the identified scales by comparing the scale-derivative norm of the canopy cover (sum of all scale-dependent components) to the scalederivative norm of permuted canopy cover (Fig. S7). Only the small-scale component could be identified from the permuted data, confirming the existence of the identified characteristic scales of variation.

\section{In step 3, the canopy cover raster map is decomposed into scale-dependent components. Following} the identification of the characteristic scales of variation, we assessed the spatial patterns of variation in canopy cover at the scales in question. We smoothed the canopy cover raster maps based on the identified scale breaks, and produced the scale-dependent components as subtractions of the smooths. The results were maps that depict canopy cover at a location relative to its surroundings, where sizes of the locations and surroundings depend on the smoothing level (i.e. with increased smoothing, larger areas are compared to their surroundings). When extracting the highest smoothing level component, we subtracted the mean of the original image from the highest smooth. We used a Nadaraya-Watson smoother with a Gaussian kernel for the smoothing (e.g., 
Scales of variation in boreal forests

253 Wand and Jones 1994). We henceforth refer to these extractions as relative canopy cover maps,

254 where each identified scale and landscape have their own map.

256 In step 4, the credibility of the canopy cover variation patterns is assessed. We used Bayesian 257 inference to account for the uncertainty stemming from the calibration models and to distinguish 258 credible variation from the visual interpretation error noise in the relative canopy cover maps. We 259 developed posterior distributions for canopy cover, based on the error in the regression model 260 between interpreted and field-measured canopy cover. We first drew a large sample from this 261 posterior predictive distribution, and approximated the posterior distribution of each relative canopy 262 cover map by applying the difference of smooths operator to each sampled image (see 263 Supplementary material 3 for details). We then identified the credibly positive and negative cells 264 from each relative canopy cover map, using simultaneous inference over all cells by applying the 265 method of highest point-wise probabilities (HPW; Erästö and Holmström 2005; Holmström and 266 others 2011), with a posterior probability threshold of 0.95.

268 In step 5, the sizes of the features in the relative canopy cover maps are assessed. To produce 269 quantifiable and comparable information at the characteristic scales of variation, we assessed the 270 sizes of the features detected in each of the relative canopy cover maps as the diameter of the 271 representative circle, an approach similar to Pasanen and others (2018). In short (see Supplementary 272 material 3 for details), for determining the diameter of a representative circular feature on each 273 relative canopy cover map, we used the smoothing level indicated by the maximum in the 274 component's scale-derivative norm and the concept of 'full width at half maximum', often used in 275 medical imaging to represent the size of a feature without clear boundaries (Epstein 2007). We note that the size estimation depended on the locations of the scale breaks, a few of which were manually 
Scales of variation in boreal forests

placed. Hence, we assessed the sensitivity of the size estimation with respect to the scale break locations. The size estimates were fairly insensitive to small changes in the scale break locations.

\section{Explanatory variables for canopy cover variation}

To assess the role of various factors driving forest structural variation at multiple scales, we assessed the relationships between relative canopy cover and recent disturbances, edaphic and topographic factors, and long-term disturbance history.

For recent disturbances, we assumed that the dead wood quantity in a cell is indicative of recent disturbances in the cell. To analyze the relationship between relative canopy cover variation and recent disturbances, we extracted the scale-dependent features of the dead wood basal area, using the same smoothing levels as with canopy cover (henceforth relative dead wood basal area; Fig. S8). The exact way in which we analyzed the relationship between relative dead wood basal area and relative canopy cover depended on the scale analyzed. At the smallest scale, we examined whether the relative dead wood basal area in a cell differed for cells with negative and positive relative canopy cover. Due to the low number of credible canopy cover cells in Quebecois landscapes, we included an additional 50 cells with the lowest and highest relative canopy cover from both Quebecois landscapes in the comparison (total 158 positive, 64 negative cells in Finnish, and 129 positive, 113 negative cells in Quebecois landscapes). For larger scales, we tested the dependency using local correlation analysis, and assessed the credibility of the correlation in each landscape (cf. Pasanen and Holmström 2017). In this analysis, we calculated Pearson correlation coefficients between the relative dead wood basal area and the relative canopy cover on a moving window. We increased window size along with the increasing smoothing level. The credibilities of 
Scales of variation in boreal forests

301 the correlations were determined by drawing a large sample from the canopy cover and dead wood

302 posterior probability distributions, using the HPW method with a credibility level of 0.95 .

304 To assess the role of site productivity and long-term disturbance history as determinants of relative 305 canopy cover, we relied on the predictability of tree species composition as a function of site 306 productivity and/or disturbance history (Supplementary material 1). We compared tree species 307 composition maps to the credible features of the relative canopy cover maps. We utilized 308 independently compiled tree species composition maps for Quebec (Ministère des Forêts, de la

309 Faune et des Parcs du Québec), based on the aerial photointerpretation of an experienced 310 interpreter. We lacked such independent maps for Finland, and therefore used tree species 311 compositions recorded during the visual interpretation of the aerial photographs, calibrated with 312 field measurements (Figs S9-S11). To ensure that the correlation between tree species composition 313 and canopy cover was not the result of including the proportion of $P$. abies in the calibration model 314 for Finnish landscapes, we also performed the calibration without $P$. abies as a predictor, and tested 315 the dependency with this model. The correlations between tree species composition and canopy 316 cover were independent of the used calibration model.

318 To assess how topography affects relative canopy cover at various spatial scales, we computed 319 topographic variables from digital elevation models with a spatial resolution of $20 \mathrm{~m}$ (National 320 Land Survey Finland, Ministère des Forêts, de la Faune et des Parcs du Québec). Variables tested 321 included elevation (mean elevation of each 0.1-ha cell), slope steepness (cell mean), slope aspect 322 (cell midpoint aspect), and topographic position (cell mean; Jenness and others 2013). If an area is 323 higher than its surroundings, its topographic position index is positive, and vice versa. We defined 324 the index on three scales: between individual cells and between groups of 10 and 20 cells. We computed Spearman's rank correlations between the means of the posterior predictive distributions 
Scales of variation in boreal forests

326 (each relative canopy cover map) and the topographic variables. If this correlation coefficient was >

3270.15 , we assessed the uncertainty of the correlation by computing correlations between the

328 particular topographic variable and all the 10000 draws of the posterior predictive distribution, and 329 assessed the mean and the $95 \%$ credibility intervals for these correlations.

\section{Results}

\section{Canopy cover and scales of variation}

336 Canopy cover in the 0.1 -ha cells ranged from 0 to $59 \%$ in the Finnish landscapes, with a posterior 337 mean of average over all cells $25 \%$ (SD of posterior predictive sample $\pm 8 \%, 95 \%$ prediction 338 interval $18-33 \%$ ) (Fig. 2 a1 - c1). Canopy cover ranged from 3 to $70 \%$ in the Quebecois 339 landscapes, with a posterior mean of average over all cells $35 \%$ ( $\mathrm{SD} \pm 13 \%, 95 \%$ prediction interval $34022-48 \%)($ Fig. 2 d $1-\mathrm{e} 1)$.

342 In the scale-derivative analysis, we identified three scales of forest structural variation in each 343 landscape, which we henceforth call large-, mid-, and small-scale variation (Fig. 3). The analysis 344 automatically identified the scale breaks between mid- and large-scale components. We manually 345 placed the scale breaks between the small- and mid-scale components at the location in which the 346 slope of the scale-derivative norm became less steep, indicating that the small-scale component 347 appeared smoothed out. The permutation test, where we compared the scale-derivative norms for 348 the canopy cover to the scale-derivative norm for permuted canopy cover confirmed the existence 349 of the identified characteristic scales of variation (Fig. S7). 
Scales of variation in boreal forests

351 Feature sizes at the largest scale identified varied among the landscapes. A typical large-scale

352 feature diameter was $2023 \mathrm{~m}$ in Hirvaskangas, $696 \mathrm{~m}$ in Pommituskukkulat and Hongikkovaara,

$353506 \mathrm{~m}$ in Lac Dionne and $1518 \mathrm{~m}$ in Pistuacanis. These diameters correspond to an area of 321.4 ha

354 in Hirvaskangas, 38.1 ha in Pommituskukkulat and Hongikkovaara, 20.1 ha in Lac Dionne and 355181.0 ha in Pistuacanis.

357 A typical mid-scale feature diameter was $190 \mathrm{~m}$ in each landscape except Hongikkovaara and Lac 358 Dionne, corresponding to a circle area of 2.8 ha. In Hongikkovaara and Lac Dionne, a typical mid359 scale feature diameter was $127 \mathrm{~m}$ (1.3 ha). The small-scale variation corresponded to the grain size 360 in our data (0.1-ha grid cells, diameter $31.62 \mathrm{~m})$ in each landscape.

362 We used the scales identified in the scale-derivative analysis to produce relative canopy cover maps 363 (Fig. 2). In these maps, negative relative canopy cover means low canopy cover in relation to the 364 surroundings, while the opposite is true for positive canopy cover. At the large scale, relative 365 canopy cover ranged from -10 to 10 percentage points in Finnish landscapes and from -13 to 10 in 366 Quebec (Fig. 2 a2 - e2). At the mid scale, relative canopy cover ranged from -13 to 15 percentage 367 points in Finnish landscapes and between -24 and 21 in Quebec (Fig. 2 a4 - e4). At the small scale, 368 relative canopy cover ranged from -15 to 18 in Finnish landscapes and between -26 and 24 in 369 Quebec (Fig. 2 a6 - e6).

371 The range of canopy cover values was greatest in Pistuacanis (Fig. 2 e1), which is reflected in the 372 relative canopy cover map intensities (Fig. 2). This intensity difference, visible in the mid- and 373 small-scale components, is also visible as differences in the scale-derivative norms (Fig. 3). 
Scales of variation in boreal forests

At the large scale, Hirvaskangas (Fig. 2 a2) and Pistuacanis (Fig. 2 e2) showed two contrasting credible canopy cover areas. We observed several smaller areas of credibly high (low) relative canopy cover in Pommituskukkulat (Fig. 2 b2), Hongikkovaara (Fig. 2 c2), and Lac Dionne (Fig. 2 d2). All five landscapes showed a higher number of credibly negative or positive relative canopy cover features at the mid scale than at the small scale, and more credible features were observed in Finnish than in Quebecois landscapes (Fig. 2 a2 - e7). Pommituskukkulat had the most credible patches of all the Finnish landscapes at the mid- and small-scales (Fig. 2 b5, b7). In Quebec, Pistuacanis landscape had the most small- and mid-scale scale credible patches (Fig. 2 e5, e7).

\section{Drivers of canopy cover variation}

\section{Recent disturbances}

At mid-scale, average correlations between relative canopy cover and relative dead wood basal area varied from -0.02 to 0.09 . However, we observed wide spatial variability in the correlations, from 0.78 to 0.83 (Fig. 4). In the Finnish landscapes, these correlations were credible in the eastern and northwestern parts of Hirvaskangas (Fig. 4f), in the middle, and southeastern part of

Pommituskukkulat (Fig. 4g), and in two areas in the middle of Hongikkovaara (Fig. 4h). Several of the mid-scale features correlated credibly with relative dead wood basal area in the Quebecois landscapes (Fig. $4 \mathrm{i}-\mathrm{j})$.

We visually judged which of the credible mid-scale canopy cover patches in Quebec likely resulted from a previous spruce budworm (Choristoneura fumiferana (Clem.)) outbreak, based on field observations. In P. mariana-dominated Lac Dionne, $10 \%$ of the credible negative mid-scale patches occurred at openings that were likely caused by the spruce budworm outbreak. In A. balsamea- 
Scales of variation in boreal forests

400 dominated Pistuacanis, $35 \%$ of the negative mid-scale patches were located at these openings. As

401 the variable examined was the canopy cover relative to its surroundings, it is also possible that the 402 loss of canopy cover due to the outbreak results in credibly positive relative canopy cover in the 403 adjacent area. Accordingly, $15 \%$ and $30 \%$ of the positively deviating patches were next to these 404 openings in Lac Dionne and Pistuacanis, respectively.

406 Small-scale relative canopy cover had a connection with relative dead wood basal area (Fig. 5).

407 In both regions, the cells with credibly positive relative canopy cover had a lower posterior 408 median relative dead wood basal area (our surrogate measure for recent disturbances) than the 409 cells with credibly negative relative canopy cover (Fig. 5). Thus, cells with high canopy cover 410 tended to have less dead wood than cells with low canopy cover. However, the relative dead 411 wood amounts did not deviate credibly from zero.

413 We did not detect large-scale correlations that would link the relative dead wood basal area (recent 414 disturbances) to relative canopy cover.

Site productivity and disturbance history

418 At the large scale, most areas with positive relative canopy cover in the Pommituskukkulat 419 landscape were in areas with a high proportion of deciduous trees (productive sites with shorter 420 time since fire than sites with higher proportion of spruce; Fig. S10-11), whereas the negative 421 relative canopy cover areas were mostly located in $P$. abies-dominated sites (old-growth productive sites). The credible large-scale features in Hirvaskangas and Hongikkovaara occurred independent 423 of tree species composition. Roughly $70 \%$ of the areas with positive relative canopy cover in Lac 424 Dionne were dominated by A. balsamea and roughly $60 \%$ of the areas with negative relative canopy 
Scales of variation in boreal forests

cover by $P$. mariana. The credible large-scale features in Pistuacanis landscape occurred independent of tree species composition.

The comparison of credible mid-scale canopy cover patches against tree species composition (our surrogate for site productivity and long-term disturbance history, see Supplementary material 1 for details) showed that sites with credible canopy cover features tended to be located in areas where tree species composition changed (Figs. S10-11). This was especially apparent in Pommituskukkulat (roughly $70 \%$ of credible mid-scale patches), Hongikkovaara (80\%), and Lac Dionne (70\%). Particularly the large mid-scale patches with credibly positive relative canopy cover in Pommituskukkulat were located in areas with a high proportion of deciduous trees (productive sites with shorter time since fire). Here, roughly $60 \%$ of the negative relative canopy cover areas were on $P$. abies-dominated productive old-growth sites. In Hongikkovaara approximately $60 \%$ of the negative patches were on P. abies-dominated productive old-growth sites. In Lac Dionne, roughly $80 \%$ of the areas with positive relative canopy cover were on A. balsamea-dominated sites (productive sites), whereas approximately $60 \%$ of the negative relative canopy covers were on $P$. mariana-dominated areas (poor sites; Figs. S10-11). In Pistuacanis, the mid-scale relative canopy cover was independent of tree species composition.

\section{Topography}

At the large scale, elevation correlated negatively with relative canopy cover in Hirvaskangas (posterior mean of Spearman's rho (r) -0.89, 95\% highest density interval (HDI) -0.90 - -0.87; Table 1), Hongikkovaara (posterior mean of $\mathrm{r}=-0.34,95 \%$ HDI $-0.38--0.30$ ), and Pistuacanis (posterior mean of $\mathrm{r}=-0.54,95 \%$ HDI $-0.56--0.51$ ). In Pommituskukkulat (posterior mean of $\mathrm{r}$ 
Scales of variation in boreal forests

$0.21,95 \%$ HDI $0.14-0.23$ ) and Lac Dionne (posterior mean of r 0.18, 95\% HDI $0.08-0.20$ ), elevation correlated positively with relative canopy cover.

Slope steepness in Hirvaskangas (posterior mean of $\mathrm{r}-0.29,95 \%$ HDI $-0.31--0.26$ ) and

Pommituskukkulat (posterior mean of $r=0.20,95 \%$ HDI $0.17-0.21$ ) and topographic position in Lac Dionne (posterior mean of $r=0.20,95 \%$ HDI $0.16-0.23$ ) correlated with large-scale relative canopy cover. Other large-scale correlations with topographic variables were negligible (Table 1).

The topographic position index at the mid-scale correlated with relative canopy cover only in Lac Dionne (posterior mean of $r=0.19,95 \%$ HDI $0.16-0.25$ ). Otherwise, mid-and small-scale relative canopy cover varied independent of topographic variables (Table 1).

\section{Discussion}

Forest structural variation occurred at discernible spatial scales, supporting our first hypothesis.

Using the scale-derivative analysis (Pasanen and others 2013), we identified three scales of distinctly hierarchical structure in the landscapes, i.e. that small-scale variation occurred within the

467 larger-scale variation levels (Kotliar and Wiens 1990; Elkie and Rempel 2001; Hay and others 468 2002), which is a characteristic feature of ecological systems (O'Neill and others 1986).

In identifying the scales of variation, we manually placed the scale breaks between the small- and

471 mid-scale, based on the changes in the slope of the scale-derivative norm. In the implemented 472 permutation test, only the small-scale component was identified, confirming the existence of the 473 discerned characteristic scales of variation (Fig. S7). This indicates that the identified scales of 
Scales of variation in boreal forests

variation did not result from a random process. Hence, despite the potential subjectivity involved in placing the scale breaks between the small- and mid-scales, the existence of all the multiresolution components was objectively verified. Further, the identification of scale breaks and multiple scales of variation is consistent with the idea of characteristic scales of variation in naturally dynamic boreal forest landscapes (natural scale steps; Scholes 2017).

The results only partially supported our second hypothesis concerning the differences of the scales of structural variation. The largest identified variation occurred at scales ranging from 20.1 to 321.4 ha, and differed most between the landscapes. In contrast, the second scale of variation (mid scale) was remarkably similar in all five landscapes, ranging from 1.3 to 2.8 ha. Qualitatively, the large(Angelstam and Kuuluvainen 2004; Bouchard and others 2008) and mid-scales (D'Aoust and others 2004; Kuuluvainen and others 2014) of variation have been recognized from boreal forests in both northern Europe and Quebec. Yet, objective quantification of these scales of variation has mostly been lacking.

\section{Traditionally in landscape ecology, landscape variability is assumed to occur as clearly delineating} patches (Kotliar and Wiens 1990). Our results imply that in addition to abrupt changes, gradual structural variability is also typical in naturally dynamic boreal forests. In the Bayesian scale space multiresolution analysis, the variation components are extracted by subtracting successive smoothing levels (Holmström and others 2011). As smoothing suppresses patch edges, features with clear edges also appear as smooth in the mid-scale component. However, if the contrast in the patch edge is strong, the mid-scale patch edges are expected to show as positive and negative bands at the patch edges, visible in the small-scale component. In our results, such banded features were not present. Furthermore, the smoothness of the corresponding patch was visible in the canopy 
Scales of variation in boreal forests

cover maps (Fig. 2 a1 - e1). Hence, our results indicate that structural variability occurs as gradual (but detectable) variability within the forest matrix.

The smallest scale of variation that we identified equaled the grain of our data, and had high variation intensity. This suggests that intense structural variability in these naturally dynamic boreal forests typically occurs at within-stand scales $(<0.1$ ha). Our choice for the grain of the data (i.e., the interpretation gird) was based on practical reasons for combining fieldwork and the photointerpretation, but also limited our analysis to scales larger than 0.1-ha. However, this scale is similar to the plot size in many (if not most) field-based studies on forest dynamics (Kuuluvainen and Aakala 2011). Hence, the significance of the small-scale variation in the boreal (e.g., Hamel and others 2004; Grenfell and others 2011), as well as the temperate zone (e.g., Runkle and Yetter 1987) has clearly been demonstrated. This applies also to both of our study regions (Pham and others 2004; Aakala and others 2016). The low number of credible small-scale relative canopy cover cells in the Quebecois landscapes is the result of their relatively high interpretation error, which is probably related to abundant regeneration following the previous spruce budworm outbreak, which occurred from the 1970s to the mid-1980s (Bouchard and Pothier 2010). In the field measurements, only trees over $10 \mathrm{~cm}$ at $1.3 \mathrm{~m}$ height were recorded. This distinction was difficult to make in the aerial photointerpretation, leading to high interpretation error.

\section{Supporting our third hypothesis, we were able to identify the scale-dependent processes creating} structural variation in the studied landscapes. The identification of different processes at particular scales also meant that these processes are underlying the patterns at that particular scale (Elkie and Rempel 2001), but also that some of the processes we examined produced patterns at multiple scales. At the largest scale identified, of the topographic variables, elevation had the strongest relationship with structural variation, although the mechanisms differed among the landscapes. In 
Scales of variation in boreal forests

523 Hirvaskangas, Hongikkovaara, and Pistuacanis landscapes, the relative canopy cover correlated

524 negatively with elevation. This suggests a productivity limitation with increasing elevation, as 525 described earlier in the North Shore region (Boucher and others 2006) and in northeastern Finland

526 (Roiko-Jokela 1980). In both regions, the differences in elevation were modest (100-150 m). Hence, 527 temperature differences are unlikely to explain these findings. Instead, we consider changes in soil 528 nutrient and moisture regimes with topography a more plausible explanation (Seibert and others 529 2007).

531 In contrast, elevation and relative canopy cover correlated positively in the Lac Dionne landscape, 532 suggesting increased productivity with increasing elevation. In boreal forests such a relationship has 533 been related to high soil water table levels at low-lying sites (Simard and others 2007), which can 534 cause structural variation even at landscape scales (Kljun and others 2006). In the Lac Dionne 535 landscape, hydric conditions likely locally limit the productivity in low-lying areas, where sparse 536 low productivity P. mariana-stands typically dominate (De Grandpré and others 2000).

538 Elevation and relative canopy cover also correlated positively in Pommituskukkulat. Here, higher 539 elevation areas were dominated by deciduous trees and had high canopy cover, whereas $P$. abies 540 stands at low elevations had low canopy cover. The areas with a higher deciduous component 541 experienced a fire in 1831 (Aakala 2018), and are separated from the areas with higher dominance 542 of $P$. abies by an open peatland running through the landscape. The peatland probably acted as a 543 fire break, creating variability within the landscape. Hence, the positive correlation between 544 elevation and relative canopy cover in Pommituskukkulat probably reflects the landscape 545 disturbance history more than an elevational effect per se (Niklasson and Granström 2000). 
Scales of variation in boreal forests

547 At the mid scale, we detected both negative and positive correlations between relative canopy cover

548 and relative dead wood basal area. The counter-intuitive positive relationship can be explained by

549 variation in soil properties. In the more productive sites, more trees equates to more dead trees,

550 while in less productive sites less trees equates to less dead trees (De Grandpré and others 2000;

551 Kuuluvainen and others 2017).

553 The negative relationship between relative canopy cover and relative dead wood basal area

554 demonstrated the role of recent disturbances in shaping forest structure, as tree mortality at these

555 scales caused reduced canopy cover relative to its surroundings. The areas we suspect were related

556 to the previous spruce budworm outbreak and windthrow areas (high numbers of similarly oriented

557 logs) in the Hirvaskangas and Lac Dionne landscapes were visible as negative correlations, and

558 showed that disturbances were responsible for creating variability at these mid scales. The larger

559 number of openings likely caused by the spruce budworm outbreak in A. balsamea-dominated

560 Pistuacanis than in P. mariana-dominated Lac Dionne is explained by the high susceptibility of $A$.

561 balsamea to spruce budworm (Hennigar and others 2008). Spatial variation in boreal forest

562 structures at these patch-scales has previously been linked with disturbances (D'Aoust and others

563 2004; Kuuluvainen and others 2014).

565 In addition to disturbances, the credible variation at the mid-scale was related to changes in tree

566 species composition, and to topography in the Lac Dionne landscape. Many of these patches were

567 located in areas where tree species composition changed. This probably reflects changes in edaphic

568 conditions or in time since the last stand-replacing disturbance, as these both affect the tree species

569 composition and tree density (De Grandpré and others 2000; Kuuluvainen and others 2017). The

570 relationship between the topographic position and the mid-scale relative canopy cover in Lac

571 Dionne is likely a result of the same process as observed at the large-scale, i.e. low topographic 
Scales of variation in boreal forests

positions associated with paludification and consequent low relative canopy cover (Lavoie and others 2007; Simard and others 2007).

We identified tree species composition, long-term disturbance history and recent disturbances as the most important drivers of mid-scale forest structural variation in both regions. However, these factors are related to soil characteristics, which influence the tree species composition (Rowe 1972; Sutinen and others 2002), and the occurrence of fires (Wallenius and others 2004; Mansuy and others 2010) in both regions. Tree mortality from the spruce budworm outbreaks that we identified as a cause for some of the mid-scale patches in the Quebecois landscapes is to a large extent influenced by the tree species composition, and concentrates especially on the A. balsameadominated stands (D’Aoust and others 2004; Hennigar and others 2008). Hence, although not directly measured here, it seems likely that the variability in soil characteristics creates patch-scale forest structural variation, corresponding to what we observed in this study.

At the small scale ( 0.1 ha, the grain of our data), we discovered a relationship between forest structural variation and recent disturbances. Earlier studies have attributed this type of 'stand-scale' variation to tree mortality (Kuuluvainen and others 1998; Aakala and others 2007), which creates structural variation especially in patches smaller than $100 \mathrm{~m}^{2}$ (Pham and others 2004). However, this small-scale variability also results from a number of other processes, including the occurrence of regeneration microsites (Grenfell and others 2011), edaphic differences (Hamel and others 2004), and tree interactions (Aakala and others 2016).

Similar to the grain of our data that excluded the within-stand variability from our analyses, it is evident that some relevant large-scale variability occurred at scales beyond the extent of the study. Most obviously, stand-replacing fires in Quebec cause variability at larger scales than we assessed 
Scales of variation in boreal forests

597 (De Grandpré and others 2000), and for example, the Lac Dionne landscape is completely within a

598 forest fire area dated to 1810 (Bouchard and others 2008). From a methodological perspective,

599 although we argue that avoiding the selection of study scales a priori is a useful approach, the

600 spatial extent and grain still obviously impose limitations on the scales that can be identified and

601 analyzed (Estes and others 2018). Here, the practical limitations related to the calibration data

602 limited the extent, but future work could benefit from the increasing availability of data that is less

603 dependent on well-distributed field plots, such as light detection and ranging (LiDAR) data.

604 However, especially in Finnish landscapes the extent is at the same time limited by the generally

605 small size of the reserves in which natural forest dynamics can be studied.

606

607 Earlier studies have attempted to describe landscape variability over multiple scales using, for

608 instance, scale space theory with blob-feature detection in the hierarchy theory context (Hay and

609 others 2002; Hay 2014), or scalograms that visualize how landscape metrics respond to changing

610 grain and extent (Zhang and Li 2013). The advantage of our approach is that the scale-derivative

611 analysis identifies the characteristic scales of variation uniformly over the entire landscape and

612 extracts the hierarchical components in a mathematically well-defined manner (Pasanen and others

613 2013), using a custom-built metric (cf. Zhang and Li 2013). Thus, it can be widely applied to

614 explore multiscale variability in any raster-form data. The scale space analysis with Bayesian

615 inference (Holmström and others 2011) allows identifying structures at the characteristic scales of

616 variation so that the error associated with the production of the raster data is incorporated in the

617 feature detection. Hence, the credibility of the variability can be assessed whenever the associated

618 error can be quantified.

620 That the scale-derivative analysis did not automatically identify all the scale breaks suggests

621 difficulties in the feature extraction due to which information close to a scale break may have been 
Scales of variation in boreal forests

622

623

624

625

626

displaced to wrong hierarchical level. It is obvious that the scale breaks may not always produce a local minimum in the norm, and instead weaker signs, such as saddle points or slope changes, should also be inspected as possible scale breaks. The ability of the scale-derivative analysis to separate scale-dependent components automatically depends on the size difference of the features within the components. The smaller the difference, the more difficult the extraction. Large feature size variation within a component and a large intensity difference between successive scaledependent components can also hamper feature extraction (Pasanen and others 2013). The difficulties in scale break identification represent a typical situation where vague scale level boundaries prove hard to detect (Scholes 2017). We also note that while placing the scale break points manually we introduced subjectivity in the scale identification process. However, small changes in the scale break locations did not cause notable changes in the size estimates and hence our analyses appear robust to this subjectivity.

The presence of the scale-dependent components, and the occurrence of credible canopy cover features in each extracted scale-dependent component supported the notion of hierarchically structured landscapes, i.e. that there were characteristic scales of variation that contain the most salient structural features (the near-decomposability in the hierarchy theory; O'Neill and others 1986). Further, we identified different factors underlying the structural variation at particular scales that is similarly expected from hierarchically structured landscapes (Wu and Loucks 1995; Wu 1999). Related to these processes, the hierarchy theory suggests that at large scales variability would be driven by processes changing slowly in time (e.g., topography), whereas at small scales the driving processes occur abruptly (e.g., disturbances) (O’Neill and others 1986; Wu 1999). The occurrence of small-scale disturbances and stand-replacing fires indicates that abrupt processes influence forest structure at local scales, as well as at scales beyond the extent of our study. In contrast, the influence of slowly changing processes was limited to large scales. 
Scales of variation in boreal forests

\section{Conclusions}

650 Our analyses showed that hierarchical structural variation can be discerned from naturally dynamic

651 boreal forest landscapes without relying on the delineation of distinct patches or on a priori selected 652 scales. Further, these scale-dependent variations are linked to a number of different processes that 653 partly crossed spatial scales (i.e. same processes created structural variation at multiple scales). 654 Except for the largest scale variation that was related to landscape-specific topography and the 655 large-scale fires typical in the North American boreal forests, the detected similarity in spatial 656 scales of variation among landscapes suggests that boreal forests may display characteristic scales 657 of variation that are somewhat independent of the dominant tree species or disturbance regime of a 658 landscape.

\section{Acknowledgements}

662 We thank Jacques Duval (Quebec Ministry of Natural Resources and Wildlife) for the aerial 663 photographs and digital elevation models for the Quebecois landscapes, Jussi Lammi and Pasi 664 Myllyniemi (EspaSystems Ltd.), and Ilkka Korpela for support in the stereointerpretation. Antti 665 Ahokas, Nora Arnkil, Stéphane Bourassa, Tapio Kara, Yasuhiro Kubota, Toshihide Hirao, Paavo 666 Ojanen, Maxime Tremblay, and Annukka Valkeapää are thanked for assistance in the field. The 667 project was funded by the Academy of Finland (proj. no 252629, 276022), Emil Aaltonen 668 Foundation, and the University of Helsinki Funds.

\section{Data availability statement}


Scales of variation in boreal forests

672 Calibration data, and the calibrated raster maps of canopy cover produced in this study will be made 673 available in Figshare at DOI:xxx/xxx upon acceptance.

\section{References}

Aakala T. 2018. Forest fire histories and tree age structures in Värriö and Maltio Strict Nature

678 Reserves, northern Finland. Boreal Environmental Research, in press.

679 Aakala T, Kuuluvainen T, De Grandpré L, Gauthier S. 2007. Trees dying standing in the 680 northeastern boreal old-growth forests of Québec: spatial patterns, rates and temporal variation. 681 Canadian Journal of Forest Research 37: 50-61.

Aakala T, Kuuluvainen T, Wallenius T, Kauhanen H. 2009. Contrasting patterns of tree mortality in 683 late-successional Picea abies stands in two areas in northern Fennoscandia. Journal of Vegetation 684 Science 20: 1016-1026.

685 Aakala T, Shimatani K, Abe T, Kubota Y, Kuuluvainen T. 2016. Crown asymmetry in high latitude 686 forests: disentangling the directional effects of tree competition and solar radiation. Oikos 125: $687 \quad 1035-1043$.

Angelstam P, Kuuluvainen T. 2004. Boreal forest disturbance regimes, successional dynamics and 689 landscape structures: a European perspective. Ecological Bulletins 51: 117-136.

690 Bouchard M, Pothier D. 2010. Spatiotemporal variability in tree and stand mortality caused by 691 spruce budworm outbreaks in eastern Quebec. Canadian Journal of Forest Research 40: 86-94. 692 Bouchard M, Pothier D, Gauthier S. 2008. Fire return intervals and tree species succession in the 693 North Shore region of eastern Quebec. Canadian Journal of Forest Research 38: 1621-1633. 694 Boucher D, Gauthier S, De Grandpré L. 2006. Structural changes in coniferous stands along a 695 chronosequence and a productivity gradient in the northeastern boreal forest of Québec. 696 Ecoscience 13: 172-180. 
Scales of variation in boreal forests

697

698

699

700

701

702

703

704

705

706

707

708

709

Bradshaw CJA, Warkentin IG, Sodhi NS. 2009. Urgent preservation of boreal carbon stocks and biodiversity. Trends in Ecology \& Evolution 24: 541-548.

D’Aoust V, Kneeshaw D, Bergeron Y. 2004. Characterization of canopy openness before and after a spruce budworm outbreak in the southern boreal forest. Canadian Journal of Forest Research 34: $339-352$.

De Grandpré L, Morissette J, Gauthier S. 2000. Long-term post-fire changes in the northeastern boreal forest of Québec. Journal of Vegetation Science 11: 791-800.

Elkie PC, Rempel RS. 2001. Detecting scales of pattern in boreal forest landscapes. Forest Ecology and Management 147: 253-261.

Epstein CL. 2007. Introduction to the mathematics of medical imaging. Society for Industrial and Applied Mathematics. 84p.

Erästö P, Holmström L. 2005. Bayesian multiscale smoothing for making inferences about features in scatterplots. Journal of Computational and Graphical Statistics 14: 569-589.

Estes L, Elsen PR, Treuer T, Ahmed L, Caylor K, Chang J, Choi JJ, Ellis EC. 2018. The spatial and termporal domains of modern ecology. Nature Ecology \& Evolution 2: 819-826.

Gauthier S, Boucher D, Morissette J, De Grandpré L. 2010. Fifty-seven years of composition change in the eastern boreal forest of Canada. Journal of Vegetation Science 21: 772-785.

Grenfell R, Aakala T, Kuuluvainen T. 2011. Microsite occupancy and the spatial structure of understorey regeneration in three late-successional Norway spruce forests in Northern Europe. Silva Fennica 45: 1093-1110.

Habeeb RL, Trebilco J, Wotherspoon S, Johnson CR. 2005. Determining natural scales of ecological systems. Ecological Monographs 75: 467-487.

Hamel B, Bélanger N, Paré D. 2004. Productivity of black spruce and Jack pine stands in Quebec as related to climate, site biological features and soil properties. Forest Ecology and Management 191: 239-251. 
Scales of variation in boreal forests

Hay GJ, Dubé P, Bouchard A, Marceau DJ. 2002. A scale-space primer for exploring and quantifying complex landscapes. Ecological Modelling 153: 27-49.

Hay GJ. 2014. Visualizing scale-domain manifolds: a multiscale geo-object-based approach. Weng JF, Weng Q, editors. Scale issues in remote sensing. John Wiley \& Sons, Incorporated. 141-169.

Hennigar CR, MacLean DA, Quiring DT, Kershaw JA Jr. 2008. Differences in spruce budworm defoliation among balsam fir and white, red, and black spruce. Forest Science 54: 158-166.

Holmström L, Pasanen L, Furrer R, Sain SR. 2011. Scale space multiresolution analysis of random signals. Computational Statistics \& Data Analysis 55: 2840-2855.

Jenness J, Brost B, Beier P. 2013. Land facet corridor designer: Topographic position index tools. http://www.jennessent.com/arcgis/land_facets.htm. Accessed 10 October 2017.

Kljun N, Black TA, Griffis TJ, Barr AG, Gaumont-Guay D, Morgenstern K, McCaughey JH, Nesic Z. 2006. Response of net ecosystem productivity of three boreal forest stands to drought. Ecosystems 9: 1128-1144.

Kotliar NB, Wiens JA. 1990. Multiple scales of patchiness and patch structure: a hierarchical framework for the study of heterogeneity. Oikos 59: 253-260.

Kuuluvainen T, Kalmari R. 2003. Regeneration microsites of Picea abies seedlings in a windthrow area of a boreal old-growth forest in southern Finland. Annales Botanici Fennici 40: 401-413.

Kuuluvainen T, Aakala T. 2011. Natural forest dynamics in boreal Fennoscandia: a review and a classification. Silva Fennica 45: 823-841.

Kuuluvainen T, Syrjänen K, Kalliola R. 1998. Structure of a pristine Picea abies forest in Northeastern Europe. Journal of Vegetation Science 9: 563-574.

Kuuluvainen T, Wallenius TH, Kauhanen H, Aakala T, Mikkola K, Demidova N, Ogibin B. 2014. Episodic, patchy disturbances characterize an old-growth Picea abies dominated forest landscape in northeastern Europe. Forest Ecology and Management 320: 96-103. 
Scales of variation in boreal forests

Kuuluvainen T, Hofgaard A, Aakala T, Jonsson BG. 2017. North Fennoscandian mountain forests: History, composition, disturbance dynamics and the unpredictable future. Forest Ecology and Management 385: 140-149.

Lavoie M, Harper K, Paré D, Bergeron Y. 2007. Spatial pattern in the organic layer and tree growth: A case study from regenerating Picea mariana stands prone to paludification. Journal of 751 Vegetation Science 18: 213-222.

752 Mansuy N, Gauthier S, Robitaille A, Bergeron Y. 2010. The effects of surficial deposit-drainage 753 combinations on spatial variations of fire cycles in the boreal forest of eastern Canada.

754 International Journal of Wildland Fire 19: 1083-1098.

755 Niemelä J, Haila Y, Punttila P. 1996. The importance of small-scale heterogeneity in boreal forests: 756 variation in diversity in forest-floor invertebrates across the succession gradient. Ecography 19: $757 \quad 352-368$.

758 Niklasson M, Granström A. 2000. Numbers and sizes of long-term spatially explicit fire history in a 759 Swedish boreal landscape. Ecology 81: 1484-1499.

760 O’Neill RV, DeAngelis DL, Waide JB, Allen THF. 1986. A Hierarchical concept of ecosystems. 761 Princeton Univ. Press. 253p.

762 Pasanen L, Aakala T, Holmström L. 2018. A scale space approach for estimating the characteristic 763 feature sizes in hierarchical signals. Stat, in press.

764 Pasanen L, Launonen I, Holmström L. 2013. A scale space multiresolution method for extraction of 765 time series features. Stat 2: 273-291.

766 Pasanen L, Holmström L. 2017. Scale space multiresolution correlation analysis for time series 767 data. Computational Statistics 32: 197-218.

768 Pham AT, De Grandpré L, Gauthier S, Bergeron Y. 2004. Gap dynamics and replacement patterns 769 in gaps of the northeastern boreal forest of Quebec. Canadian Journal of Forest Research 34: 353770364. 
Scales of variation in boreal forests

771 Robitaille A, Saucier J-P. 1998. Paysages régionaux du Québec méridional. Les Publications du 772 Québec. Sainte-Foy, CA [In French].

773 Roiko-Jokela P. 1980. Maaston korkeus puuntuotantoon vaikuttavana tekijänä Pohjois-Suomessa.

774 Folia Forestalia 452: 1-30 [In Finnish with English summary].

775 Rowe JS. 1972. Forest regions of Canada. Environment Canada, Ottawa.

776 Ruel J-C, Pin D, Cooper K. 1998. Effect of topography on wind behaviour in a complex terrain.

$777 \quad$ Forestry 71: 261-265.

778 Runkle JR, Yetter TC. 1987. Treefalls revisited: gap dynamics in the Southern Appalachians.

779 Ecology 68: 417-424.

780 Scholes RJ. 2017. Taking the mumbo out of the jumbo: progress towards a robust basis for

781 ecological scaling. Ecosystems 20: 4-13.

782 Seibert J, Stendahl J, Sørensen R. 2007. Topographical influences on soil properties in boreal 783 forests. Geoderma 141: 139-148.

784 Simard M, Lecomte N, Bergeron Y, Bernier PY, Paré D. 2007. Forest productivity decline caused 785 by successional paludification of boreal soils. Ecological Applications 17: 1619-1637.

786 Sutinen R, Teirilä A, Pänttäjä M, Sutinen M-L. 2002. Distribution and diversity of tree species with 787 respect to soil electrical characteristics in Finnish Lapland. Canadian Journal of Forest Research $788 \quad 32: 1158-1170$.

789 Walker X, Johnstone JF. 2014. Widespread negative correlations between black spruce growth and 790 temperature across topographic moisture gradients in the boreal forest. Environmental Research $791 \quad$ Letters 9, https://doi.org/10.1088/1748-9326/9/6/064016.

792 Wallenius TH, Kuuluvainen T, Vanha-Majamaa I. 2004. Fire history in relation to site type and 793 vegetation in Vienansalo wilderness in eastern Fennoscandia, Russia. Canadian Journal of Forest $794 \quad$ Research 34: 1400-1409.

795 Wand MP, Jones MC. 1994. Kernel smoothing. Chapman and Hall/CRC. 224p. 
Scales of variation in boreal forests

796 Wickland KP, Neff JC. 2008. Decomposition of soil organic matter from boreal black spruce forest:

797 environmental and chemical controls. Biogeochemistry 87: 29-47.

798 Wong CM, Daniels LD. 2016. Novel forest decline triggered by multiple interactions among

799 climate, an introduced pathogen and bark beetles. Global Change Biology 23: 1926-1941.

800 Wu J. 1999. Hierarchy and scaling: extrapolating information along a scaling ladder. Canadian

$801 \quad$ Journal of Remote Sensing 25: 367-380.

802 Wu J, Loucks OL. 1995. From balance of nature to hierarchical patch dynamics: a paradigm shift 803 in ecology. The Quarterly Review of Biology 70: 439-466.

804 Zhang N, Li H. 2013. Sensitivity and effectiveness and of landscape metric scalograms in 805 determining the characteristic scale of a hierarchically structured landscape. Landscape Ecology $806 \quad 28: 343-363$. 
Scales of variation in boreal forests

Table

808

809 Table 1. Spearman's rank correlation coefficients between the relative canopy covers at the

810 detected scales ( $\mathrm{SS}=$ small-scale, $\mathrm{MS}=$ mid-scale, $\mathrm{LS}=$ large-scale $)$ and the topographic variables

811 for the 0.1 -ha cells.

\begin{tabular}{|c|c|c|c|c|c|c|c|c|c|c|c|c|c|c|c|}
\hline & \multicolumn{3}{|c|}{ Hirvaskangas } & \multicolumn{3}{|c|}{$\begin{array}{c}\text { Pommitus- } \\
\text { kukkulat }\end{array}$} & \multicolumn{3}{|c|}{ Hongikkovaara } & \multicolumn{3}{|c|}{ Lac Dionne } & \multicolumn{3}{|c|}{ Pistuacanis } \\
\hline & SS & MS & $\mathrm{LS}$ & SS & MS & $\mathrm{LS}$ & SS & MS & LS & SS & MS & LS & SS & MS & $\mathrm{LS}$ \\
\hline Elevation & 0.00 & -0.10 & -0.89 & 0.01 & 0.06 & 0.21 & 0.01 & -0.01 & -0.34 & 0.00 & -0.01 & 0.18 & 0.00 & -0.06 & -0.54 \\
\hline $\begin{array}{l}\text { Slope } \\
\text { steepness }\end{array}$ & -0.01 & -0.07 & -0.29 & 0.01 & 0.09 & 0.20 & 0.02 & 0.04 & -0.07 & 0.01 & -0.02 & -0.09 & 0.01 & -0.02 & 0.12 \\
\hline $\begin{array}{l}\text { Slope } \\
\text { aspect }\end{array}$ & 0.01 & 0.12 & -0.07 & 0.00 & 0.02 & -0.11 & -0.01 & -0.03 & 0.03 & 0.00 & -0.02 & -0.04 & 0.01 & 0.02 & -0.04 \\
\hline TPI & 0.01 & 0.01 & -0.05 & 0.01 & 0.07 & 0.09 & 0.03 & 0.09 & -0.08 & -0.01 & 10.19 & 0.20 & 0.01 & -0.01 & 0.11 \\
\hline
\end{tabular}

812

813 


\section{Figures}

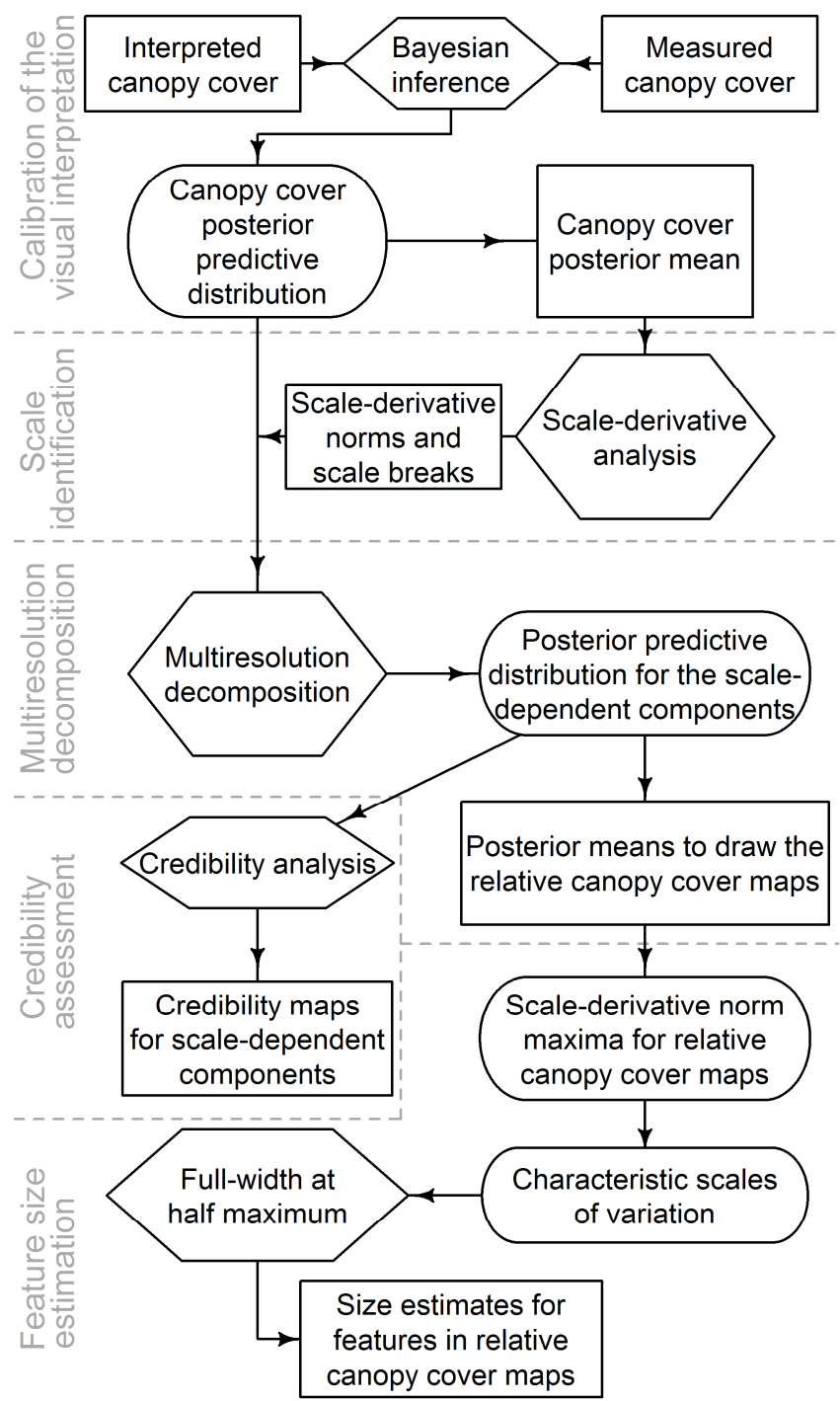

815

816 Figure 1. The analysis workflow. The rectangles represent input and output data, the hexagons are

817 analyses, and the rounded rectangles transitional stage data. 

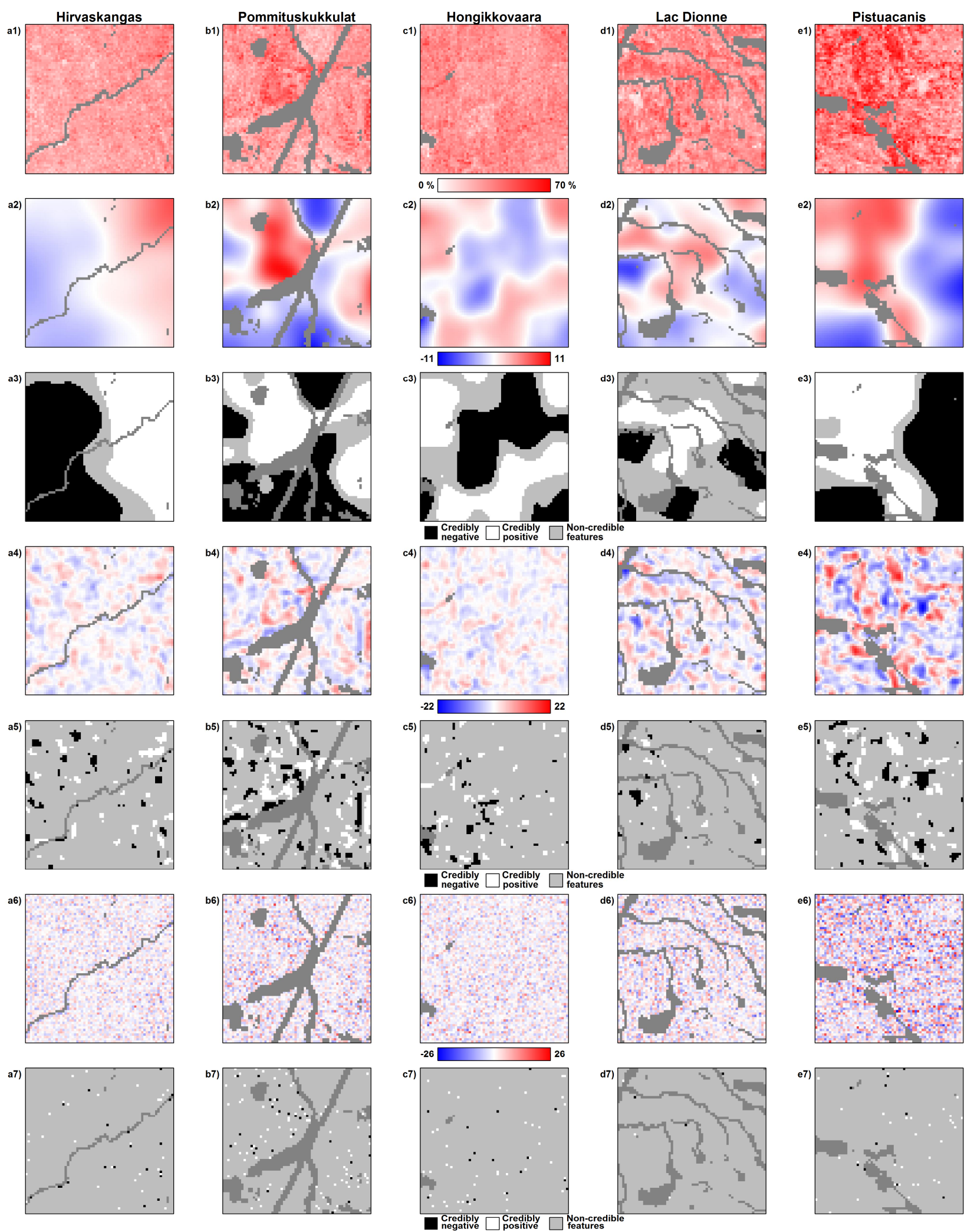

819 Figure 2. Canopy cover maps of the study landscapes, canopy cover in the 0.1-ha cells (a1 - e1).

820 The large-scale relative canopy cover maps (a2 - e2) and their credibilities (a3 - e3), the mid-scale

821 relative canopy cover maps (a4-e4) and their credibilities (a5 - e5), and the small-scale relative 
Scales of variation in boreal forests
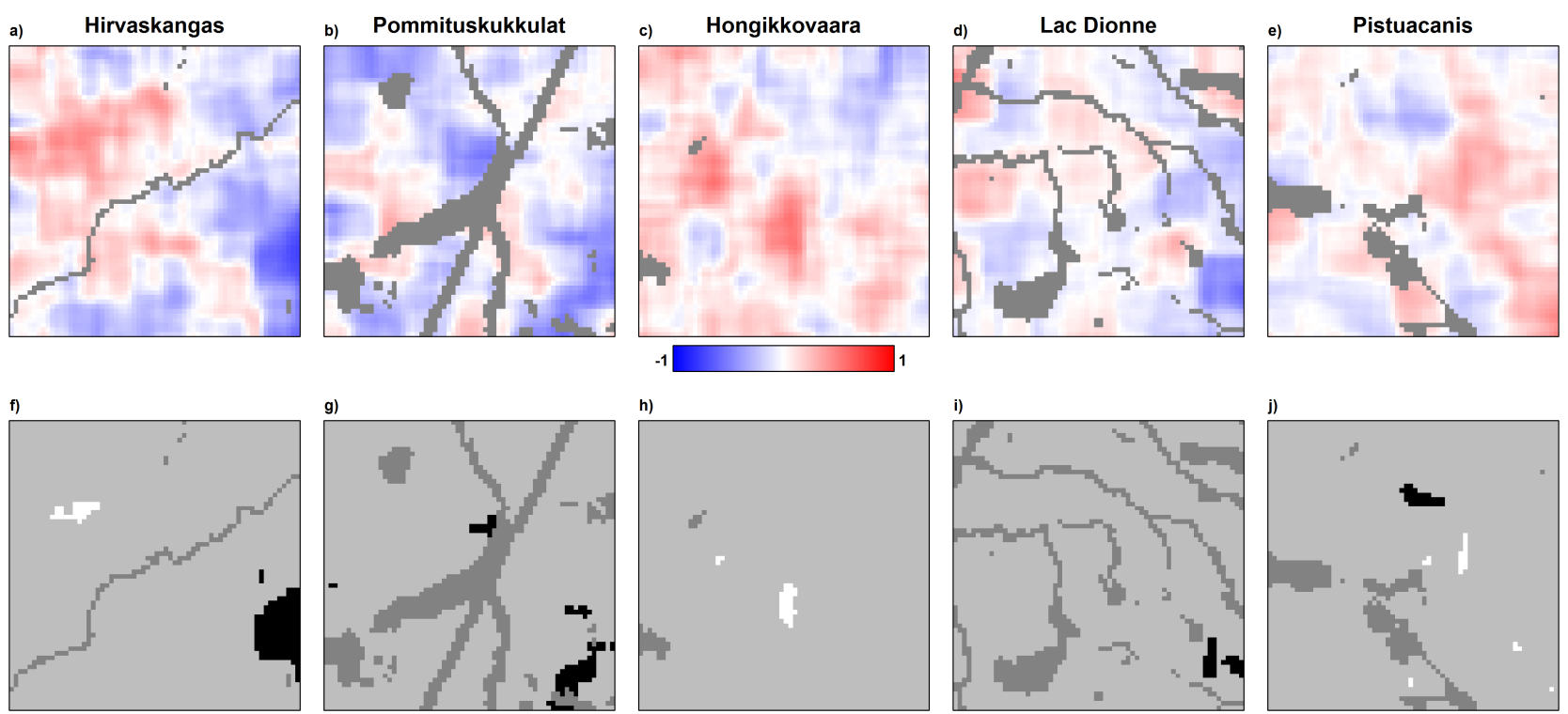

831 Figure 4. Local Pearson correlations at the mid scale between relative canopy cover and relative

832 dead wood basal area (posterior mean values, $a-e)$, and their credibilities $(f-j)$. Dark gray cells
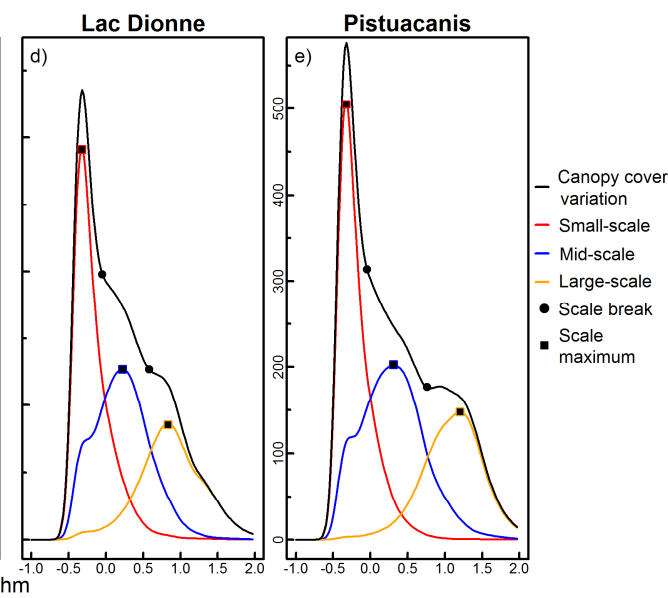

Figure 3. The scale-derivative norms as a function of the smoothing parameter logarithm. The colored lines show individual components. The points represent the component scale breaks and the squares depict the components' local maxima. N.B. the ten-raised smoothing parameter values and the different $y$-axis scale in the Pistuacanis landscape.
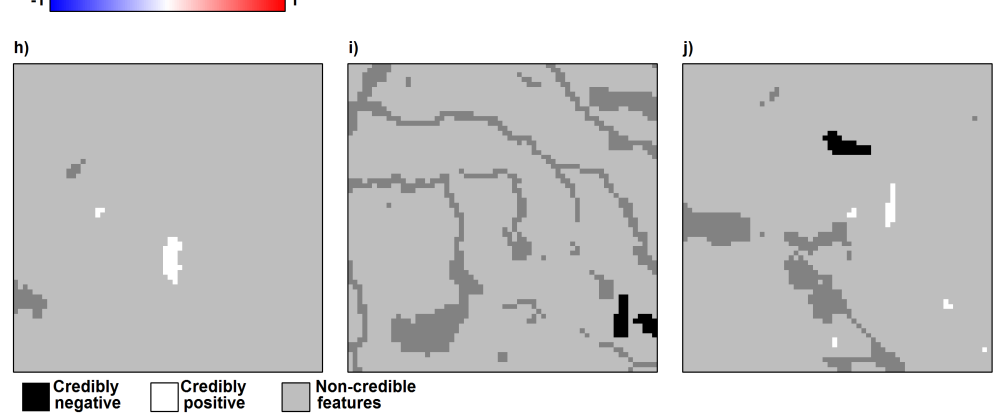

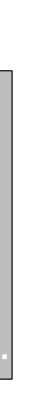


Scales of variation in boreal forests

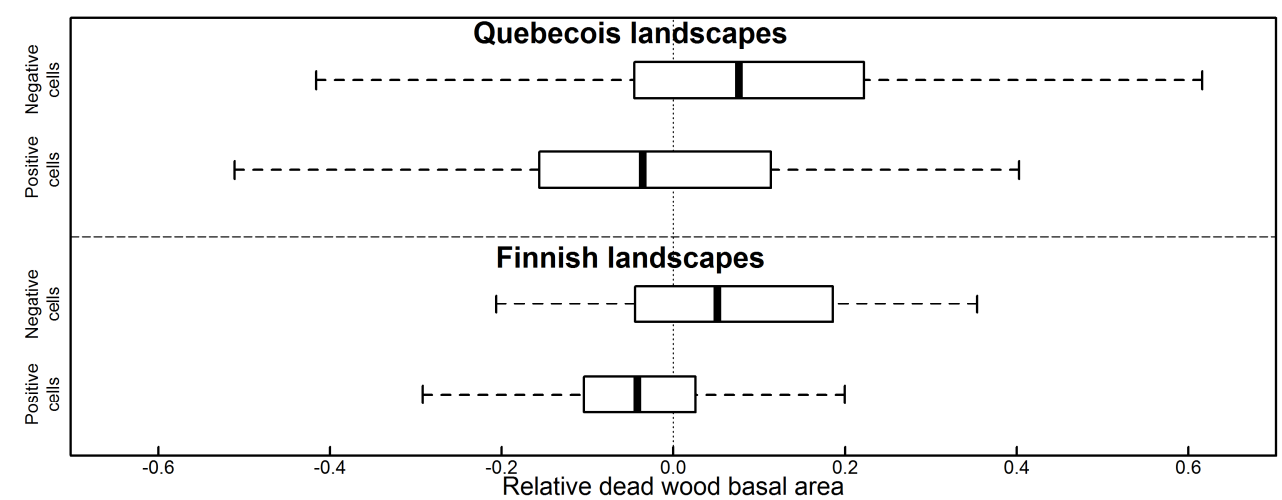

835 Figure 5. The posterior distributions of the relative dead wood basal area medians in the small-scale 836 cells with credible relative canopy cover. The distributions consist of 158 positive and 64 negative 837 cells in the Finnish landscapes and 129 negative and 113 positive cells in the Quebecois landscapes.
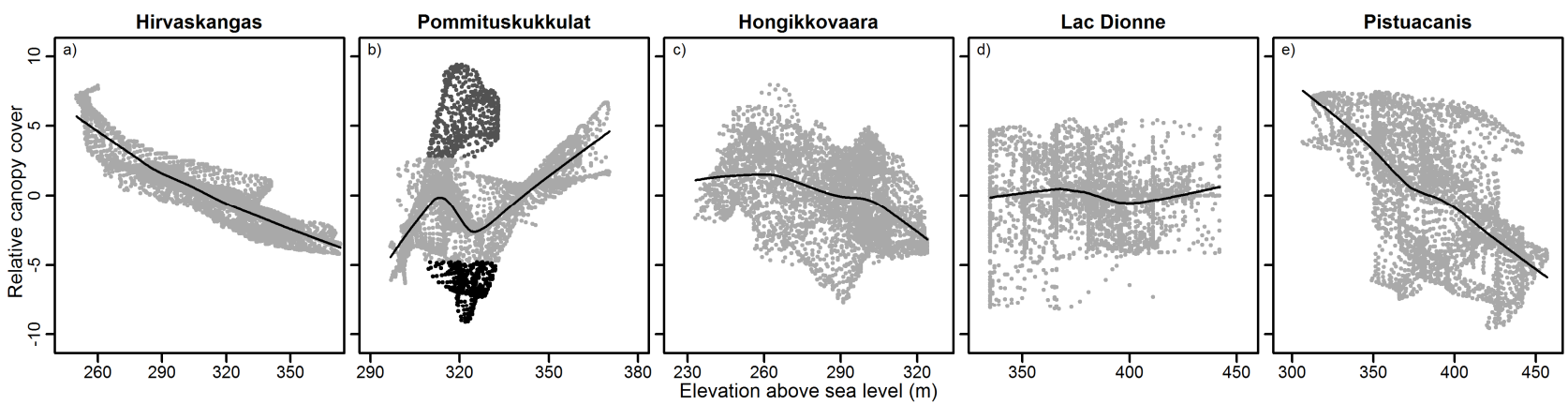

839 Figure 6. Large-scale relative canopy cover in relation to elevation in the studied landscapes,

840 illustrated with a lowess regression. Pommituskukkulat (b) landscape has areas that clearly deviate

841 from the main pattern. Here, the dark gray dots represent a birch-dominated area, and the black dots

842 represent a hilltop spruce-dominated area. The light gray dots form the main pattern. 